\title{
Effects of Motivation of School Administrators on Human Resources Management
}

\author{
Oğuzhan Cebeci, Çağda Kivanç Çağanağa \\ Institute of Graduate Studies and Research, European University of Lefke, Mersin, Turkey \\ Email: cagda4@yahoo.com
}

How to cite this paper: Cebeci, O. and Çağanağa, C..K. (2019) Effects of Motivation of School Administrators on Human Resources Management. Open Access Library Journal, 6: e4808.

https://doi.org/10.4236/oalib.1104808

Received: July 30, 2018

Accepted: July 23, 2019

Published: July 26, 2019

Copyright $\odot 2019$ by authors and Open Access Library Inc.

This work is licensed under the Creative Commons Attribution International License (CC BY 4.0).

http://creativecommons.org/licenses/by/4.0/

(c) (i) Open Access

\begin{abstract}
One of the strategical elements of educational system is school administrators. Willingness to work of school administrators that means motivation of them is important from the point of sustainable success in education sector. The aim of this research which started from this point is to find out the conditions which increase or decrease motivation of administrators during their mission. It's thought that the findings obtained from the research are important, therefore to draw attention to professional life of school administrators, to increase perception on personal rights and labor conditions, and to enlighten management of human resources of administrators. This research is planned and implemented by qualitative research method. Participant group of the research is consisted from 10 school administrators. Semi-structured interview technique is used for data collection. "Content analysis" is performed in the research. The research reveals that there are many parameters that most of them derive from environmental and public themes which have positive or negative effects on motivations of school administrators. It's seen that "personal rights, peace among employees and being interested by Ministry of Education" are the most positive motivators for school administrators, but "rumor, uneasiness among employees and responsibility beyond authority" are demotivation factors. In this research, effects of increasing and decreasing on motivation of school administrators on human resources management are also analyzed as well as motivation of school administrators. Increasing of motivation of school administrators has positive effects on themes as relationship of administration-employees, peace on working settings, willingness to work of employees-productivity; on other hand, decreasing of motivation has opposite effects as problems on administration-employees relationship, unjust treatment to staffs, negative effects on themes as willingness to work of employees-productivity and debonair approach. Since being successful and productive of school administrator effects reaching to goals and success of education system where they work, motivation sources and ef-
\end{abstract}


fects of them on human resources are deemed an important issue that should be analyzed by researchers.

\section{Subject Areas}

Education

\section{Keywords}

Motivation, School Administrator, Human Resources

\section{Introduction}

Educational institutes of a country are important partner of the education system and success of the institute is also deemed as the success of this system. Since the mission of school administrator is "to carry out the management affairs" [1], success of school administrator is also seemed as success of education system as well as success of the school. From this point of view, it's possible to say that the most strategic element of the system is school administrators. Therefore, willingness to work of school administrators could bring success for education system, and motivation of administrators has importance as well as motivation of lower level employee as in the other sectors. Inasmuch as one of the functions of an administrator is to make leadership express reconciliation between personal needs and organizational goals by recruiting, removing, motivating and supporting [2].

In generally, motivation of employees who work under their administrators for their works which are directed to goals of the organization is also important for productivity and success of organization in the sector which it belongs. But, administrators of an organization are also individuals who have feelings, goals, careers, labors and responsibilities besides being administrators in direction with organizational goals of the organization. Therefore, it's seen that motivation of administrators for their mission is important both for organizational success and contented and productive working of employees. So, considering of motivation of administrators as well as motivation of educational and assisting personnel's could have an important positive effect on aimed organizational success while designing the investment and measures for human resources management which is planned in the context of productivity and management of personnel by political and bureaucratic decision makers for success of schools which are placed in the educational system. In addition, assumption that has effects on personal, social, economic and environmental factors has an impact on motivation of school administrators as well as organizational factors, which should be taken in account. Because of these assumptions, reasons that affect the motivation of school administrators both in positive and negative direction and human resources of schools are mentioned in the research. 


\section{Scope of Motivation Concept}

According to [3], motivation term is rooted from French word "motivation" and translated as "encouragement". But it's preferred to use "enthusiasm for doing something" terms in academically studies and publishes in Turkish.

Motivation is the total forces that drive and ensure continuity of peoples' actions and endeavor. Those following three main factor should be considered while defining of motivation process:

1) The force that compel or cause an organism for an attitude,

2) The force provides progressing of a behavior in a certain way,

3) The force provides protecting and sustaining of a behavior after emerging, [4] [5].

These factors explain motivation by relationship with treating way to individuals and feeling of them about the work they performed. Instead of this, [6] expresses another definition of motivation as is effecting wage earners for performing their mission in accordance with expecting qualification and quantity. Otherwise [7] states that primarily human needs were emphasized in previous researches by analyzing major definition for motivation and then expressed that behavior about meeting needs should be directed to a purpose related with organization.

It can be said that Maslow Theory is most common motivation theory that explains human behaviors. Humanist psychologist Maslow who were the most interested in value and power of human, has also considered the distinction between healthy and unhealthy individuals and has believed that they had positive power to change their life quality. His opinions and theories have affected opinions and theories on administrative sciences. Maslow has formed motivation theory that has covered five fundamental needs as physiologic, security, social, dignity and self-fulfillment [8]. From his point of view, an individual efforts for meeting of physiologic necessaries as nutrition and sleeping that are fundamental for maintaining of human life in first step then needs for safety as accommodation, protection, warming are satisfied, following them social needs that provide to help being integrated to the society are met. When we considered point of view of administrators and employees of an organization which belongs to education system we see that these individuals are persons who met their physiologic and safety needs in term of educational and economic competence. In that case, we can say that social needs, dignity and self-fulfillment are the needs that given priority by this administrators and employees who work in an organization. Already it can be said that working and specialized in a work is a precondition for self-fulfillment for an individual in a social life. Because of these reasons, administrators and employees who involved to an educational organization should have better working motivation and being successful, to smell of success by contribution of this motivation for carry on the organization to success in the direction of organizational goals. By this way, an individual could see the effect of the motivation that reached to it himself or provided motivation to 
him that has a contribution on the success of organization and could want to make it steady. And this could bring permanent success to the organization.

\section{Importance of Motivation for School Administrator}

Administration defines as "managing, oversight, dominion, governing, conducting" according to dictionary. Administration is a universal concept which analyses the relationship of a person with the other people's consequence of need for social life of human and their behaviors in the face of various factors [9]. If we take it for educational institutions, we can define administration as activities performed by administrators of an organization using both infrastructure and human resources and also source of authority for the purpose of managing strategically to reach of organizational goals. Looking to the defining in this area, it could be finding that administration is an organization process and its implementation is on employees.

There must be an administrator in an organization where administration is performed. In the point of view of the structure, human resources and potentials of organization "Administrator is to define briefly as the one who is enactor" [10]. [11] states that there is a necessity of properly providing and directing of human and material sources by school administrators. But administrator should provide encouraging conditions both in working environment and in the sense of social relationship and entity to supply giving right decisions on time about their missions in this period by considering that the employees of the organization are distinct personalities while giving decisions. Can (2005, s. 234) states about this period that one who carry out administration work should know these needs, could analyze their behaviors and realized that all of them are different from their each other. Administrators, who recognize this strategy are in search of motivate to their employees by providing these conditions to reach goals of organization. [2] explains this situation as individuals in an organization should be motivated for success of their mission in effective and productive way. By this way it's possible to make working persons happy and have job satisfaction. Success of organization will follow it. Administrator is one of the individuals in an organization as it could be understood from definition. From this point of view motivation is a need should be met for administrators as well as employees. But in education sector, it's generally accepted that, one of the task of administrator is to motivate of teachers before their motivation needs. [12] explains this task of administrators as the duty of administrators is to motivate teachers and increase their productivity and provide their work satisfaction.

Yet there is not more information for motivating factors of administrators. This motivation matter should be research and analyze in the context of motivation of school administrators. Do school administrators need to be motivated? What does motivate school administrators? Answers of these kind questions are not emphasized and researched for administrators as well as school employees.

[13] has also stated that there is not any research that directly mentioned moti- 
vation sources or factors that decreases motivation of school administrators, but there are a few ones indirectly enlighten their motivation in his research on this issue.

[5] has pointed to motivation that related with attitudes against people and feelings of them about their work. School administrators have expectations and senses for their works, attitudes against to them, needs for their work in their working environment from their institute, higher authority and surroundings as well as teachers. School administrators could have expectations from higher authorities about their duty and responsibilities as well as other employees. Therefore the school administrators whose expectations would not be met could have unwillingness and underperformance on management skills, belonging to the organization, human resource management. A school administrator, who is in that situation, could not direct existing institutional and human resources on desired level and productivity for school aims and success. This position could negatively influence school administration and success [14]. So, implementing of an education program directed to the reasons motivating and demotivating factors of school administrators could make a positive turn on management and success of education on national level by legislators and legislator officers.

\section{Human Resources Management and Motivation}

According to [15], human resources cover all the employees from top executive to unqualified worker and also include actively take advantage of labor from out of institute as well as related with work force in institute. Effective planning and managing of human resources in an institute is possible to recognizing of employed staffs and analyzing of personnel qualifications who would work on related positions.

[16], has mentioned that productivity of institutes is one of the priority matter and source of the productivity is human factor into the institute with all dimensions. Therefore expected attitude from administrator in the sense of human resources to provide organizational productivity is: First of all, administrators should recognize that the staffs took charge in the organization are human; and come close to them considering that they have concerns, aims, expectations and feelings and encourage them in the direction with their duty.

A person has various needs as a psycho-social creature. Some of these needs are physiologic and concrete needs. Some of them are spiritual needs that much more abstract, invisible but have more importance. Elimination of these needs and personalized facilities provides satisfying of them. And this satisfaction has influence on personal performance. For example wage that deserved from his job, eliminates purchasing needs of a person. Otherwise, work motivation causes job satisfaction and being happy from his job. So, there is a directly relationship between needs and motivation of a person. If we remind that human resource management is invite to eliminate human needs in principle, it could conclude that this discipline aimed to motivate an individual in a sense. Therefore, em- 
ployees would be more motivated when their needs met. According to [17], motivation results conformity of personnel to general purposes of institute and devotion to these purposes and creating of we-feeling and job-satisfaction. Inadequate motivation leads to perception of "me" instead of "us", decreasing of cooperation and increasing of tension. It is thought that the sociological situations expressed here in terms of the employees in the context of human resources and motivations are also valid in terms of administrators and school administrators who are research subjects because "school director is also a human" [18]. Therefore it supposed that school administrators need motivation as well as employees both to carry out their duty in frame of productivity and willingness, and effective management of human resources that they administrate as well as employees.

It's considered that the way to do their job of administrators and employees with conscientiously and in accordance with organizational goals are depend on their happiness in process of their job and how to find or not to find solutions to their problems. So, detecting of strategies to meet need for motivation of employees and administrators in business life and situation which could make unhappy by both senior manager or junior administrative officer or bureaucrats and planning appropriate working conditions could be important for long term success. In related this issue, [19] states that research has revealed that recognizing of satisfaction and concerns which derive from a person's own work life is important realizing of expectations from him and being successful. Determination of these needs and strategies for administrators as well as employees in and education institute could provide to prevent negative conditions that would be exposed administrators and affect their performance in negative way. An administrator who feels unhappy would be indifferent and even below average for himself and human resource management that he carries out. [20] expresses this situation as people who feels disgruntled and sad could not be productive. Therefore it's thought that effective management of an institute in all aspects, administrators should feel good mentally in both social and business environment and it's important to provide conditions to realize it. In accordance with this matter, [21] point out that a healthy administrator is the heart or foundation stone of an organization. One of the most strategical factors of education system is school administrator. Therefore, willingness to work that's mean motivation of an administrator is important for successfully management of human resources and hence organizational success. Aim of the research is to reveal reasons that increase or decrease motivation and effects of them to human resources management in organizations. Results of research could be helpful to draw attention to professional business life of school administrators in both social and administrative aspects and could upgrade understanding to personal rights in positive manner. For this purpose, depending on the expressions of school administrators we search answers to following questions related to statements of school administrators: 
1) What are the circumstances that increase your motivation as school administrator?

2) What are the circumstances that decrease your motivation as school administrator?

3) What are the effects of increasing motivation to your human resource management?

4) What are the effects of decreasing motivation to your human resource management?

\section{Methodology}

The research is a qualitative research based on investigating the reasons that increasing or decreasing factors of motivation of school administrators in management process and effects of these causes on the management of human resources in their institutions. Phenomenology pattern technique is used in the research. [22], explains phenomenology pattern as to focus on phenomenon that we are in aware but not to have deepen and detailed understood about them. During the research situational approach is adopted for deal with opinions of individuals. [23] defines situational approach as a qualitative research approach that deeply analyzes limited one or more situation with data collecting tools, defines situations and themes depending on the situation.

\subsection{Study Group}

Study group of the research is consisted from 10 school administrators. Schools that would be making interviews have identified by considering the amount of schools depended to Cypriot National Education Ministry-Primary Education Office for consisting of study group which would be based to the research. During the planning of interviews 15 administrators were specified, but 10 of them have accepted to attend the research. The study group is consisted by choosing school administrators according to Maximum Diversity Sampling which could be suitable to this research. The aim of using Maximum Diversity Sampling method is to consist a relatively small sampling and to reflect diversity of individuals' who could be a party of problem which is dealing in the sampling according to [22]. For this reason, diversity is provided by considering professional seniority, undergraduate degree, managerial title and educational status. Indicators related with school administrators that regarding participant group are shown in Table 1.

\subsection{Data Collecting Tools}

Semi-structured interview technique is used for data collecting technique during the research. According to [24], this technique is neither as rigid as the structured interview, nor as flexible as non-structured ones; it's between two extremes. Semi-structured interview technique used for it provides practicability in preparation, implementation and analyze processes. Research and analyzing of 
Table 1. Data of school administrators who are in the participant group.

\begin{tabular}{|c|c|c|c|}
\hline Variances $n=10$ & & $\mathrm{f}$ & $\%$ \\
\hline & Male & 6 & 60 \\
\hline \multirow[t]{5}{*}{ Gender } & Female & 4 & 40 \\
\hline & Total & 10 & 100 \\
\hline & $31-35$ & - & - \\
\hline & $36-40$ & 1 & 10 \\
\hline & $41-45$ & 3 & 30 \\
\hline \multirow{5}{*}{ Age } & $46-50$ & 3 & 30 \\
\hline & $51+$ & 3 & 30 \\
\hline & Total & 10 & 100 \\
\hline & $10-15$ & 1 & 10 \\
\hline & $16-20$ & 2 & 20 \\
\hline \multirow[t]{4}{*}{ Professional Seniority } & $21-25$ & 3 & 30 \\
\hline & $26+$ & 4 & 40 \\
\hline & Total & 10 & 100 \\
\hline & School Principal & 6 & 60 \\
\hline \multirow[t]{2}{*}{ Managerial Title } & Deputy Head of School & 4 & 40 \\
\hline & Total & 10 & 100 \\
\hline
\end{tabular}

national and international academically publishing has done for object and subject of this research, before clarifying questions in the interview form. After identifying conception frame and target group, criteria which considered placing into interview form are defined. The questions asked to school administrators in the survey are as following:

1) What are the circumstances that increase your motivation as a school administrator?

2) What are the circumstances that decrease your motivation as a school administrator?

3) What are the effects of increasing motivation to your human resource management?

4) What are the effects of decreasing motivation to your human resource management?

These items were consulted with two faculty members, a Ph.D. student and three school administrators for the purpose of analysis, meaning and scope of analysis. After these procedures, final form of the questionnaire which was constructed by using obtained data was shaped after assessment of a linguist for language and semantic and distributed to the individuals to the target of the research.

The data within the scope of the research were obtained from interviews with determined school administrators on May 1 and May 2017. Every interview with 
each participant has extended about 30 minutes. According to [25], an interview is a purposefully conversation where questions prepared by researcher in advance are asked and answered by the other person. Voice recorder was used to prevent losing of data during the interviews. It's informed to participants that, interview would be recorded during the conversation and this record could listen by participant after the workout, if they ask to delete some part or all of the record, it would be done. By this way it's tried to prevent the negative effect of voice recorder on interviewed person and ask for permission for voice record during interviews. During implementing of interview form, attention paid to preparation of an environment in which interviewees could feel comfortable, safe and peaceful and state their expressions easily, a suitable ambiance designed to purpose of research and transfer of information from individuals. Researcher effect was made neutral during response of participants. Professional career of researcher is primarily mentioned to provide safety during implementation of interview questions (his experience as a teacher and deputy administrator). Participants were informed about the processes that needed to know from the beginning to the end of the research.

\subsection{Analysis of Data}

"Content analyze" made in the stage of assessment of research. According to [26], Content analyze is to make inferences about written and non-clear content features from written and explanatory features of social truth. Data are analyzed by coding of findings, detection of encoded findings, arranging of themes and codes and commenting of defining of findings. During these processes, primarily interview voice records and written interview forms are detected and analyzed. It has made classification according to similarity and paralleling of statements for analyzing of statement of participants. Code numbers have given to school administrators who were consulted during analysis (Y1, Y2...) and necessary explanations were made. Finding that obtained by interview technique are converted numerical data and expressed as frequency value and percent (\%).

To ensure the internal validity of the study:

1) Circumstances that increase and decrease motivation of administrators and effect of increasing or decreasing motivation to human resources are encoded. Descriptive analysis technique was used to draw attention to the codes obtained in this period. According to [27], this technique is to quote from opinions of participants to reflect their opinions by considering the questions in interview form. By this way, integrity and meaningful of findings were controlled continually.

2) To ensure meaning and coherence of findings, data that were sources to themes area analyzed for consistency both in themselves and with the other themes and controlled if they have become meaningful data.

3) Findings were compared with the other research if they were consonant with them.

4) Created themes were specified and commented by induction or deduction 
according to their contents.

5) Obtained findings are analyzed by school administrators who were chosen from participant sampling and it's stated that they were realistic findings by them.

6) It's seemed that findings of the research are consistent with literature survey which made in the stage of planning of research and forecasting based on professional experience.

For having external validity of this research:

1) Preparation and implementation period of the research is explained in details in the frame of preparing, implementation and analyzing of materials which data would be obtained.

2) Data and obtained results were compared with the other research in that field and endeavored to reach real the means of results and situations in practice.

3) Needed explanations are made by detail to analyze with the other researches.

4) With the appropriate school administrators who were consulted were re-interviewed and the results were shared and checked.

\section{Findings}

Findings are shown in four parts:

1) Circumstances that increase motivation of school administrators.

2) Circumstances that decrease motivation of school administrators.

3) Effects of increased motivation on human resources management.

4) Effects of decreased motivation on human resources management.

1) Circumstances That Increase Motivation of School Administrators

Circumstances that increase motivation of school administrators are shown in Table 2 by analyzing findings that obtained from interviews.

Table 2. Circumstances that increase motivation of school administrators.

\begin{tabular}{clc}
\hline S.N. & \multicolumn{1}{c}{ Encoded Reasons That Increase Motivation } & f \\
\hline 1 & Personal rights (Wage, social rights, seniority, etc.) (Y1, Y2, Y3, Y4, Y6, Y7, Y8, Y9) & 8 \\
2 & Peace among employees (Y2, Y4, Y5, Y6, Y7, Y8, Y9) & 7 \\
3 & Interest of the Ministry (Y1, Y3, Y4, Y5, Y6, Y7, Y9, Y10) & 7 \\
4 & Interest of parents (Y1, Y2, Y3, Y5, Y6, Y9) & 6 \\
5 & Enjoying the profession (Y2, Y6, Y7, Y8, Y9, Y10) & 6 \\
6 & Well-appointed personnel (Master, Ph. D. etc.) (Y1, Y2, Y4, Y5, Y10) & 5 \\
7 & Discipline (Y1, Y3, Y7, Y8) & 4 \\
8 & Job-satisfaction (Y2, Y3, Y5, Y7) & 4 \\
9 & Success of students (Y2, Y3, Y4, Y10) & 4 \\
10 & Physical and material possibilities of the school (Y1, Y2, Y10) \\
11 & Interest of environment (Y4, Y6) & 3 \\
12 & Transparency (Y7) & 2 \\
\hline
\end{tabular}

*Y; Encoded school administrator. 
It can be seen that 12 encoded circumstances increase the motivation of school administrators. When we detect the circumstances of motivation source that have higher frequency than 4 are placed in Table 2: "Personal rights (wage, social rights, seniority, etc.) $(f=8)$, peace among employees $(f=7)$, interest of the Ministry $(f=7)$, interest of parents $(f=6)$, enjoying the profession $(f=6)$, well-appointed personnel (master, ph. d. etc.) $(f=5)$, discipline $(f=4)$, job-satisfaction $(\mathrm{f}=4)$, success of students $(\mathrm{f}=4)$.

When the situations that increase motivation are examined, it seems that the most motivated thing for school administrators is to have adequate personnel rights. It's clear that the other motivation sources for school administrators as peace among employees, the Ministry, parents, enjoying profession and well-appointed personnel are related with human resources. Some of the statements of school administrators about encoded circumstances which make increased their motivation are as follow:

"If the financial return of this responsibility that we take and the job we have done would be better, my motivation would be increased", Y2. "Most important motivation source in my institute is peace among employees. If working environment is in peace, I would be in peace and my motivation is increased", Y3. "Interest of the Ministry to us and school make me more motivated", Y6. "Of course appreciate of the Education Ministry to school administrators and concerned and sensitive parents increase our motivation", Y1. "Contributing to education of our children for the future of our country makes me happy, and then it makes me motivated. Therefore I love my profession", Y4. "Both our success and motivation would be increased if we have much more teacher who have master graduate and Ph.D.”, Y2. "Discipline is very important. Being disciplined both for students and employees could make easier to manage, therefore motivation would be increased", Y3. "When I enjoy my job, the satisfaction I get from work is also increasing. This affects my motivation positively", Y7.

2) Circumstances That Decrease Motivation of School Administrators

Circumstances that decrease motivation of school administrators are shown in Table 3 by analyzing of findings obtained from interviews.

Motivation of school administrators is decreased by 14 encoded circumstances. When the circumstances decreased motivation of administrators is examined the most demotivation source that have higher frequency than 4 are placed in Table 3 are: Rumor, $(f=8)$, unrest among employees $(f=7)$, responsibility beyond the authority $(f=7)$, economic problems $(f=7)$, indifference of the Ministry $(f=6)$, indifference of parents $(f=6)$, lack of physical and financial resources of the school $(f=6)$, bureaucratic obstacles $(f=6)$, lack of desire of employees to work $(f=5)$, wrong education policies $(f=4)$, intervention of politicians and bureaucrat $(\mathrm{f}=4)$.

Most of the demotivation factors for school administrators are seems like related with human resources which are unrest among employees, the Ministry, parents, bureaucracy, personnel as motivation factors and educational policies, 
Table 3. Circumstances that decrease motivation of school administrators.

\begin{tabular}{cll}
\hline S.N. & \multicolumn{1}{c}{ Encoded Reasons That Decrease Motivation } & f \\
\hline 1 & Rumor (Y1, Y2, Y4, Y6, Y7, Y8, Y9, Y10) & 8 \\
2 & Unrest among employees (Y1, Y2, Y4, Y6, Y7, Y8, Y9, Y10) & 7 \\
3 & Responsibility beyond the authority (Y1, Y3, Y5, Y7, Y8, Y9, Y10) & 7 \\
4 & Economic problems (Y1, Y4, Y6, Y7, Y8, Y9, Y10) & 7 \\
5 & Indifference of the Ministry (Y1, Y3, Y4, Y5, Y9, Y10) & 6 \\
6 & Indifference of Parents (Y1, Y4, Y5, Y6, Y9, Y10) & 6 \\
7 & Lack of physical and financial resources of the school (Y1, Y2, Y3, Y4, Y5, Y6) & 6 \\
8 & Bureaucratic obstacles (Y1, Y2, Y3, Y4, Y5, Y7) & 6 \\
9 & Lack of desire of employees to work (Y1, Y2, Y5, Y6, Y8) & 5 \\
10 & Wrong education policies (Y2, Y3, Y6, Y7) & 4 \\
11 & Intervention of politicians and bureaucrats (Y1, Y2, Y3, Y10) & 4 \\
12 & Injustice approaches to the administrators (Y3, Y5, Y8) & 3 \\
13 & Health problems (Y1, Y2, Y4) & 3 \\
14 & Students failure (Y2, Y4) & 2 \\
\hline
\end{tabular}

*Y; Encoded school administrator.

policy, public administration, which effect society and system. However the frequency is lower, it's seen that health problems are also influence motivation. From this point of view, negative conditions in job could cause adaptation problems and uneasiness, effect mental health and lead to decreasing of individual performance at work. [28] points out the relation stress due to professional conditions with psychological problems and expressed the relation with depression in a research on administrators. [29] has stated that in many research it was proved that administrators in the face of stress have exposed more stress than employees. According to the findings of the research circumstances that decrease motivation are parallel with increasing circumstances. This parallelism is an ordinary situation according to the problem that was asked because these two questions which were asked with same problem sentences are inquiring the opposite situations. Some of the statements of school administrators about encoded circumstances which make decreased their motivation are as follow:

"Some rumors made by some staffs are effects both my and the other employees motivation", Y6. "Unrest among teachers cause deal with other new problems as well as already existed ones. This causes a decreasing in motivation", Y4. "There is a negative effect on me because of the responsibility which doesn't match with the authority that given by the Ministry, and pressure of it", Y5. "Despite the long working times, the low wage we receive causes economic stress. It effects our motivation", Y3. "Every kind of economic works that we wanted to perform, we have to make personal contact with politicians because of there is not adequate fund from the Ministry and they don't have necessary in- 
terest to these activities. This causes decreasing of motivation", Y5. "Indifference of parents prevent my motivation sometimes", Y8. "The fact that the school is not supported economically and not appreciated the works that have done, break my willingness to work and that's decrease my motivation", Y2. "Resistance and delaying of teachers to given tasks, effects our motivation", Y4.

3) Effects of Increasing Motivation to Your Human Resource Management

Effects of increasing motivation of administrators to human resources which obtained analyzing of data of interviews are shown in Table 4.

In examination of effects of increasing motivation of school administrators to human resources management, it seems there are 8 different encoded circumstances. The circumstances that have mean frequency for researched problem and show the effects to human resources management are (Table 4): Management-personnel communication $(f=9)$, peace of work environment $(f=8)$, willingness to work of staff and productivity $(f=7)$, gracious approach to employees $(f=7)$, team work $(f=6)$, justification in work distribution ( $(f=5)$, participation of staff to decisions $(f=4)$, better supervision and transparency $(f=4)$. It's seen that management-personnel communication and peace in working environment are having more positive effect of increasing motivation on human resources management. Also willingness to work of staffs and productivity and gracious approach of administrators to employees has meaningful effect. These relationships have shown that there is a connection in the dimension of human resources as personnel, communication, peace in working environment, productivity, and team work same as in the other problem articles of this research. This has shown that positive increasing on motivation of administrators could affect human resources management and supported the research. Some of the statements of school administrators on circumstances that effects of increasing motivations to human resources management:

"I have more healthy communication with teachers when I motivated, I could

Table 4. Effects of increasing motivation of school administrators to human resources management.

\begin{tabular}{|c|c|c|}
\hline S.N. & $\begin{array}{c}\text { Encoded Circumstances That Show the Effect of Increasing Motivation to } \\
\text { Human Resources Management }\end{array}$ & f \\
\hline 1 & Management-personnel communication (Y1, Y3, Y4, Y5, Y6, Y7, Y8, Y9, Y10) & 9 \\
\hline 2 & Peace of work environment (Y1, Y3, Y5, Y6, Y7, Y8, Y9, Y10) & 8 \\
\hline 3 & Willingness to work of staff and productivity (Y1, Y2, Y4, Y5, Y7, Y9) & 7 \\
\hline 4 & Gracious approach to employees (Y2, Y3, Y5, Y7, Y8, Y10) & 7 \\
\hline 5 & Team work (Y4, Y6, Y7, Y8, Y10) & 6 \\
\hline 6 & Justification in work distribution (Y1, Y4, Y5, Y8, Y9) & 5 \\
\hline 7 & Participation of staff to decisions (Y2, Y4, Y6, Y7) & 4 \\
\hline 8 & Better supervision and transparency (Y1, Y2, Y3, Y4) & 4 \\
\hline
\end{tabular}

${ }^{\star}$ Y; Encoded school administrator. 
approach them more positively", Y2. "Our working environment becomes more productive when we are motivated. If I have positive approach to my staff, they would become more positive to me. So, this prevents unrest conditions", Y5. "If an administrator is motivated, he could have better relationship with teachers. Therefore teachers could work more happy and willingness", Y7. "I feel happy when motivated. I have become gracious to teachers, if I'm happy", Y9. "Personnel who work with a good motivated administrator aware of this and it reflects to teamwork", Y4. "I do much more objective delegation to teachers when I'm happy and motivated," Y2. "I think I consult more with related teachers when I highly motivated", Y3.

\section{4) Effects of Decreased Motivation on Human Resources Management}

Effects of decreased motivation of administrators to human resources which obtained analyzing of data of interviews are shown in Table 5.

In examination of effects of decreased motivation of school administrators to human resources management, it's seen there are 6 different situations. The circumstances that have mean frequency for researched problem and show the effects to human resources management are (Table 5): Management-personnel communication $(f=9)$, injustice approaches to employees $(f=9)$, decline on willingness to work and productivity of personnel $(f=6)$, prejudiced inspection $(f=5)$, Decline in problem solving skills of management $(f=4)$, decline in school-environment relation $(f=2)$. It's seen that management-personnel problems and injustice approaches to employees have more effects than the others to decreased motivation on human resources management. Also prejudiced inspects and decline in problem solving skills of management have meaningful effect. It reveals that there is a relationship with human resources aspect as well as in the other questions that this research tries to find answer but in negative manner. From this point of view it shows and support that, decreasing on motivation of administrators could have negative effect on human resources management. Some of the own statements of school administrators on circumstances that decreased motivation of school administrators to human resources management are as follow:

Table 5. Effects of decreased motivation on human resources management.

\begin{tabular}{|c|c|c|}
\hline S.N. & $\begin{array}{l}\text { Encoded Circumstances That Show the Effect of } \\
\text { Decreased Motivation to Human Resources Management }\end{array}$ & f \\
\hline 1 & Management-personnel communication (Y1, Y3, Y4, Y5, Y6, Y7, Y8, Y9, Y10) & 9 \\
\hline 2 & Injustice approaches to employees (Y1, Y2, Y3, Y4, Y6, Y7, Y8, Y9, Y10) & 9 \\
\hline 3 & $\begin{array}{l}\text { Decline on willingness to work and productivity of personnel (Y1, Y2, Y3, Y6, Y8, } \\
\text { Y10) }\end{array}$ & 6 \\
\hline 4 & Prejudiced inspection (Y1,Y2, Y3, Y4, Y7) & 5 \\
\hline 5 & Decline in problem solving skills of management (Y1, Y2, Y5, Y8) & 4 \\
\hline 6 & Decline in school-environment relation (Y2, Y3) & 2 \\
\hline
\end{tabular}

${ }^{*}$ Y; Encoded school administrator. 
"I could have more problem with teachers if my motivation decline", Y2. "There could be some injustice approach to employees if we are demotivated and under stress", Y6. "Teachers would be stressed if administrators are unhappy and stressed", Y8. "We couldn't be objective when motivation is lower", Y6. "An administrator who is restless and nervous couldn't solve the problems properly, unless he would be motivated," Y7.

\section{Conclusion and Discussion}

When the circumstances that increase and decrease the motivation of school administration for their mission examined, it's seen that they are cumulated around environmental themes which have higher frequency besides the personal themes as health, job satisfaction, and love of profession in low frequency. It's seen that there are 12 different encoded but related with their each other circumstances which increase the motivation of school administrators. It is seen that these situations are related to the ministry, personal rights, personnel, student, parents dimensions, which is mean human resources. Also it could be seen that school administrators have expectation for connection and relationship from these environments. It is found that there are 14 different encoded but related with their each other circumstances which decrease the motivation of school administrators. When the circumstances increasing and decreasing motivation are compared, it is seen that they are parallel for the opposite situations analyzed for the same problematic situation. Furthermore, there are 12 circumstances that increase the motivation of school administrators, but 14 circumstances that decrease their motivation. This outcome has shown that school administrators have much more problem and have to handle with more negative conditions therefore they become demotivated.

In this research, according to the response of participants, it has shown that circumstances as personnel rights, interest of the ministry, peace among employees, loving profession are the increase motivation of school administrators.

Also in the light of the statements of participants, when the circumstances that decrease motivation of school administrators are analyzed, it's revealed that individuals (authorities from the ministry, bureaucrats, politicians, teachers and parents) are important as a factor. This outcome could be related with lack of common vision, goal, awareness and sensibility on national education.

In the research, it's found that the effect of increased motivation of school administrators to human resources management is cumulated on circumstances that have related themes with human resources as management, personnel, working environment, teamwork and inspection. When the effects of increasing and decreasing of motivation are compared, it's seen that they are parallel for the opposite situations analyzed for the same problematic situation. Furthermore, there are 8 circumstances that increase the motivation of school administrators, but 6 circumstances that decrease their motivation. This has shown that human resources management process is effect multi-dimensional and perceivable, 
however, for effect from demotivation, it's limited according to motivation. This outcome reveals that administrator who was motivated or demotivated is effects human resources management, but increased motivation has much more effective on human resources accordingly vice versa. Therefore in the planning stage for success of education system both long and short term, measures to increase motivation of administrators as well as employees in the context of human resources for effective and productive leading of staffs are important manner should be emphasized.

In accordance with response of participants who were asked their opinions it's come out that increased motivation of school administrators have positive effect on management-personnel relationship, peace in working environment, productivity of personnel and willingness to work, gracious approach to employees and teamwork. The consequence is that decreasing of motivation would have a negative effect on these aspects. From this point, it's clear that for effective human resources management, it's necessary to motivate administrators as well as employees. Therefore "School principals are also human" (Açıalın, 2006). If administrator could not be motivated enough, this situation may be reflected to human resources in a negative manner. [17] points out that lack of motivation could emerge "me" instead of "us" in an institute and cause some kind of tensions by removing cooperation ambiance.

As conclusion; it's thought that giving necessary importance to individuals who conduct managing and administrating work is strategically important for administrating of schools which are an important partner of fundamental education system, in direction of targeted purposes and in productive manner. Since school administrators could be motivated to be successful as the other administrator in professional business life, their success could be appreciated and be supported with encouraging rewards or personal rights. Lack of interest of senior administrations, bureaucratic obstacles, need for appreciation effect their motivation in negative way, so ministry-school administrator communication could be make more transparence and reachable and bureaucratic obstacles for appeals related needs of schools could be improve by support of a professional working team. To increase the interest of parents and environment to schools, supportive projects that include parents and environment could be encouraged. Some professional studies could be performed by the Ministry and related partners in the context of reaching to a shareable vision which is a common goal of all of the education sector employees in educational mean. Universities and related professionals can develop scales that can analyze personal and organizational motivation levels and needs of school administrators. Relationship of personal motivation levels of school administrators and school human resources management could research in deeply.

\section{Conflicts of Interest}

The authors declare no conflicts of interest regarding the publication of this paper. 


\section{References}

[1] KKTC MEB (1985). 25/1985 sayılı KKTC ÖğretmenlerYasası. Resmi Gazete. 52 (Teachers Law of Turkish Republic of Northern Cyprus).

[2] Can, H. (2005) Organizasyonve Yönetim. Siyasal Kitabevi, Ankara.

[3] Türk Dil Kurumu (Turkish Language Association). http://www.tdk.gov.tr

[4] Özgener, Ş. (2000) Gelişmekte Olan Ülkelerde İş Görenin Güdülenmesive Tky’nin İşgörenin Güdülenmesine Katkıları. S.Ü. Sosyal Bilimler Meslek Yüksekokulu Dergisi, Sayı: 4.

[5] Keenan, K. (1996) Motivasyon. Çev: Ergin KOPARAN. Remzi Kitabevi, Istanbul.

[6] Başaran, I.E. (1992) Yönetimde İnsan İlişkileri: Yönetsel Davranış. Gül Yayınevi, Ankara.

[7] Pekel, H.N. (2001) İşletmelerde Motivasyon Verimlilik İlişkisi. Süleyman Demirel Üniversitesi Sosyal Bilimler Enstitüsü, Yayınlanmamış Yüksek Lisans Tezi, Isparta.

[8] Çetinkanat, A.C. (2002) İşdoyumuvetükenmişlik. Eğitim Araştırmaları Dergisi, No. 9, 186-193.

[9] Güney, S. (2001) Yönetimve Organizasyon. Nobel Yayınevi, Ankara.

[10] Aytürk, N. (1990) Yönetimsanatı: Başarılı Yönetimve Yöneticilik Teknikleri. Nobel YayınEvi, Ankara.

[11] Taymaz, H. (2003) İlköğretimve Ortaöğretim OkulMüdürleriİçin “Okul Yönetimi”. PegemAkademiYayıncılık, Ankara.

[12] Karaköse, T. and Kocabaş, İ. (2006) Özelve Devlet Okullarında Öğretmenlerin Beklentilerinin İş Doyumuve Motivasyon Üzerine Etkileri. Eğitimde Kuramve Uygulama, 2, 3-14.

[13] Yıldırım, N. (2011) Okul Müdürlerinin Motivasyonları Üzerine Nitel Bir İnceleme. AİBÜ, Eğitim Fakültesi Dergisi, 11, 71-85.

[14] Sabuncuoğlu, Z. (1997) Personel Yönetimi: Politikave Yönetsel Teknikler. Uludağ Üniversitesi, Bursa.

[15] Açıkalın, A. (1994) Çağdaş Örgütlerde İnsan Kaynağının Personel Yönetimi. Pegem A Yayıncilık, Ankara.

[16] Fındıkçı, İ. (2000) İnsan Kaynakları Yönetimi. Alfa Yayınları, İstanbul.

[17] Açıkalın, A., Şişman, M. and Turan, S. (2007) Birİnsan Olarak Okul Müdürü. Pegem A Yayıncilık, Ankara.

[18] Güven, A. and Akyüz, M.Y. (2002) Okul Yöneticilerinde Kayg1 İş Doyumu İlişkisinin İncelenmesi. Eğitim Araştırmaları Dergisi, 7, 178-188.

[19] Alıç, M. (1996) Eğitim Sistemi Amaçlarının Gerçekleştirilmesinde Eğitim Yöneticisinin İşlevleri. Çağdas Ĕ̆itim Dergisi, 217, 12-16.

[20] Quick, J.C., Frey, M.M. and Cooper, C.L. (2007) Guest Editors' Introduction: Managerial Dimension of Organizational Health: The Healthy Leader at Work. Journal of Management Studies, 44, 189-205.

https://doi.org/10.1111/j.1467-6486.2007.00684.x

[21] Yıldırım, A. and Şimşek, H. (2008) Sosyal Bilimlerde Nitel Araştırma Yöntemleri. Seçkin Yayıncılık, Ankara.

[22] Creswell, J.W. (2007) Qualitative Inquiry and Research Design: Choosing among Five Traditions. 2nd Edition, Sage, London.

[23] Karasar, N. (1995) Bilimsel Araştırma Yöntemi. 3A Araştırma Eğitim Danışmanlık, Ankara. 
[24] Kuş, E. (2003) Sosyal Bilimlerde Araştırma Teknikleri Nitel mi, Nicel mi? AnıYayıncılık, Ankara.

[25] Arık, A. (1992) Psikolojide Bilimsel Yöntem. İstanbul Üniversitesi Basımevi, İstanbul.

[26] Türnüklü, A. (2000) Eğitimbilim Araştırmalarında Etkin Olarak Kullanılabilecek Nitel Bir Araştırma Tekniği: Görüşme. Kuram ve Uygulamada Ĕ̌itim Yönetimi Dergisi, 6, 543-559.

[27] Baltaş, A. and Baltaş, Z. (1990) Stres ve başa çıkma yolları. Remzi Kitabevi, İstanbul.

[28] Erdoğan, T., Ünsar, S. and Süt, N. (2009) Stresin Çalışanlar Üzerindeki Etkileri: Bir Araştırma. Süleyman Demirel Üniversitesi İktisadi ve Ídari Bilimler Dergisi, 14, 447-461.

[29] Ekinci, H. and Ekici, S. (2003) İşletmelerde Örgütsel Stres Yönetim Stratejisi Olarak Sosyal Desteğin Rolüne İlişkin Görgül Bir Araştırma. Cumhuriyet Üniversitesi Sosyal Bilimler Dergisi, 27, 109-120. 